\title{
O TRABALHO DO ATOR E SUAS COMPETÊNCIAS FUNDAMENTAIS NA CENA CONTEMPORÂNEA
}

Os atores sempre se confrontaram com a questão do reconhecimento de procedimentos técnicos na fundamentação de seu ofício. E nesse sentido, a arte da representação foi objeto de diferentes pesquisas que apontaram inúmeras formas de estruturação e instrumentalização, diferentes procedimentos de treinamento e trabalho.

A convivência na cena contemporânea com uma multiplicidade estética, cujas formas de representação são por vezes divergentes, vem fomentando o ator a uma busca inquieta de uma semelhante multiplicidade de técnicas de representação. É, então, compartilhando, como ator, desta mesma inquietude sobre as competências fundamentais necessárias ao ator para responder às demandas da cena contemporânea, que faço deste espaço um momento de reflexão sobre alguns aspectos da arte do ator: qualidades fundamentais do ator sobre a cena, modalidades de apropriação do texto dramático e caracterização do personagem, compreensão dos conceitos de energia e presença cênica, relação entre técnica, intuição criadora e cristalização do personagem.

Escolhi desenvolver esta reflexão a partir do entendimento adotado por atores gaúchos sobre estes aspectos, traçando aproximações e reconhecendo suas divergências. Nesse sentido, o procedimento metodológico se definiu primeiramente pela realização de entrevistas para as quais foi traçado um roteiro estruturado. Saio a campo e entrevisto doze atores e atrizes de Porto Alegre, buscando contemplar diversas gerações, formações, participantes de grupo estável ou não: Arlete Cunha, Daniel Colin, Dejayr Ferreira, Evelyn Ligocki, Giancarlo Carlomagno, Luciane Panisson, Luiz Paulo Vasconcellos, Marcelo Aquino, Rodrigo Marques, Sandra Dani, Simone Butelli e Tânia Faria.

Procuro fundamentar teoricamente a análise das entrevistas com os estudos sobre a relação entre verdade cênica e vivência emocional, segundo Stanislavski, necessária para o ator realista do início do século XX. Com igual valor, abordo a concepção antagônica a essa primeira revelada pela supermarionete de Gordon Graig, que se revoltou contra o teatro de sua 
época, teatro esse que ele acreditava estar repleto de atores a procura de sua própria beleza. Formula a noção da marionete, ou seja, o ator apenas como mais um elemento do teatro e não o seu centro, o ator que era completamente controlado pelo encenador e não um artista livre para criar e usar de suas emoções. Também Meyerhold que, ao contrário de Stanislavski, acreditava que o ator deveria ter consciência que está representando, desassociando-se do personagem, e que, dessa forma, desenvolve um estudo mais aprofundado do movimento do ator, o que vem a chamar de biomecânica. E, por fim, os estudos de Brecht e seu teatro épico, cujo objetivo didático e político priorizava o distanciamento do ator de seu personagem, em prol do ensino e da sociedade. $O$ ator passa a desdramatizar a ação, ou seja, a invés de existir uma linha de narrativa com desfecho, essa linha era interrompida constantemente para reflexão e comentários.

Faz-se importante salientar que evitarei as digressões naturais de um processo de entrevista em favor dos aportes significativos no âmbito de cada aspecto investigado.

\section{O Ator e a cena contemporânea}

É natural o teatro, como forma de expressão de uma sociedade, modificarse com esta sociedade. Assim, vê-se hoje um teatro bem diferente daquele feito por Stanislavski, Craig, Meyerhold, Brecht e tantos outros.

Tomemos como exemplo alguns grupos brasileiros significativos e veremos a cena contemporânea que exemplifica estas mudanças. As encenações do grupo paulista Vertigem sobre a utilização da memória dos espaços urbanos como parte integrante da linguagem dos seus espetáculos, serve de exemplo de um dos grupos mais sintonizados com os temas do teatro contemporâneo. Vide a trilogia do grupo: Paraíso Perdido, O Livro de Jó e Apocalipse 1,11, que provoca impacto no público brasileiro.

Foi quando Araújo resolveu convidar um grupo de atores para ler e experimentar.

Por quase um ano, o grupo de atores se reunia das oito da manhã à uma da tarde para fazer o treinamento do método Laban, estudar a transposição de conceitos de física clássica para o trabalho do corpo do ator e ler textos. Nenhuma peça de teatro dava conta dos temas 
que atormentavam aquelas almas. Acharam mais fácil elencar que temas seriam esses. Chegaram a um só: lugar do sagrado no cotidiano deles, jovens artistas de terceiro mundo em fim de milênio. [...] Começaram então um processo que é uma das características do grupo até hoje, a elaboração da dramaturgia em parceria com o dramaturgo.[...] Além do trabalho de criação do texto, do espetáculo e de seus elementos, os atores ainda participaram de treinamento de Laban, improvisação de contato (outra técnica de dança) e acrobacia (Labaki. In: Nestrowski, 2002).

O trabalho do ator, como podemos observar, não se concentra apenas na construção de um personagem, e sim na construção de um espetáculo inteiro, inclusive na dramaturgia em si, revelando uma filiação inconsciente própria da formação do ator brasileiro.

Processos semelhantes, onde atores exercem não só a função de representar, como também encampam o papel de dramaturgos, podem ser observados também nos trabalhos do teatro Oficina de José Celso Martinez Correa, no CPT de Antunes Filho ou no trabalho do grupo Asdrúbal Trouxe o Trombone de Hamilton Vaz Pereira.

Junto a isso, cumpre observar outro importante aspecto: 0 ator se encontra como instrumento biológico desse meio. É ele que dá vida ao sonho e à criatividade de todos os envolvidos no processo teatral. Então, faz-se rigorosamente importante organizar o pensamento e a constituição de um artista tão essencial para nossa arte. Arte que perde espaço para a imagem mecânica e luta para preservar o que há de vivo no ser humano. Jean Pierre Ryngaert coloca muito bem a situação em que se encontra $O$ ator face ao triângulo que constitui o fazer teatral na atualidade:

\begin{abstract}
O teatro repousa, desde sempre, sobre o jogo entre o que está escondido e o que é mostrado, sobre o risco da obscuridade que de repente faz sentido. A representação, derrisória em seu próprio projeto, esfalfa-se para mostrar o mundo em cena com os meios rudimentares do artesanato de feira e pela linguagem.[...] Isso ainda é verdade, mas hoje em dia não completamente, já que existem outros meios de representação além do teatro, bem mai "verdadeiros", principalmente as imagens filmadas[...] Vem daí, provavelmente, um primeiro mal-entendido entre os que escrevem e encenam o teatro de hoje e os que assistem a ele. Existe uma grande distância entre o teatro tal como é e tal como é percebido ou, em todo caso, segundo a idéia que se faz dele (Ryngaert, 1998, p.5).
\end{abstract}

Frente a estes dois aspectos levantados, podemos concluir que o ator encontra-se deste modo na cena contemporânea: profissional que perde 
espaço para o cinema e que descobre novas perspectivas de técnicas de representação elegidas por mudanças fundamentadas na realidade da sociedade desse ator, perspectivas que exigem teorias mais fundamentadas ainda não estruturadas neste início de século.

\title{
2. Concepção e procedimentos técnicos de abordagem da personagem no texto dramático
}

\begin{abstract}
O ator desempenhando um papel ou encarnando um personagem, situa-se no próprio cerne do acontecimento teatral. Ele é o vínculo vivo entre o texto do autor, as diretivas de atuação do encenador e 0 olhar e a audição do espectador (Pavis, 1999, p.30)
\end{abstract}

O entendimento da função do ator no acontecimento teatral, bem como a noção de personagem, evoluiu ao longo dos tempos, acompanhando as mudanças do próprio teatro. Na Grécia Antiga, o vocábulo ator designava a máscara, isto é, a pura representação do personagem. Nesse sentido, o ator estava separado de seu personagem servindo apenas como seu executante. "Até o século VII, o termo ator designava a personagem da peça", destaca Patrice Pavis em seu Dicionário de Teatro e continua: "em seguida, aquele que tem um papel, o artesão da cena e o comediante". Na época romântica, o ator é aquele que encarna um personagem, uma presença física mantendo uma relação e mostrando ao público essa força que ela carrega, fazendo com que ele se identifique com tal personagem.

É certo que o ator contemporâneo deixou para trás essa concepção única de ser um atuante apenas, como se a sua função se limitasse a mostrar o personagem. $O$ ator atualmente quer representar seu personagem levando em consideração a sua encenação ciente do paradoxo que acompanha a sua função: dar vida a um ser presente somente no papel sem deixar de ser ele mesmo. Esse ator não se contenta mais em apenas reproduzir o texto dramático. Ele quer ser um elemento integral no processo de criação do espetáculo. Isso é fruto de todas as transformações advindas dos estudos de teóricos já previamente mencionados e de outros. 
simples personagem, mas do texto e de sua encenação (Pavis, 1999, p. 30).

Dentro da concepção natural-realista, Stanislavski planta uma série de princípios de atuação que compreendem o personagem enquanto identidade psicológica. Durante anos de estudos sobre o trabalho do ator, Stanislavski lutava para conquistar a sinceridade na interpretação. Durante a primeira fase de sua pesquisa, denominada "Psicotécnica", acreditava que os atores deveriam estabelecer as vontades dos personagens para facilitar o jogo teatral e a buscar a emoção verdadeira do ator usada em prol de seu personagem. Rigorosamente fundamentado pelo seu trabalho e em vários outros estudos sobre o comportamento humano, Stanislavski acreditava que o ator deveria controlar sua emoção em cena sem bloqueá-la. Aconselhava que o ator deveria saber usar a sua emoção na hora exata através de um estudo detalhado da função de seu personagem naquele texto, as suas vontades e intenções onde o psíquico desencadeia o físico.

Para que isso aconteça, Stanislavski propunha que o ator trabalhasse movido por seu subconsciente, fazendo apelo ao que chamou de memória emotiva, ou seja, lembrar de algo que Ihe foi marcante na vida real poderá desencadear uma emoção pertinente ao personagem naquele dado momento. Ou ainda, a utilização do subtexto como ponto de partida das ações. O subtexto da fala do ator tem uma segunda intenção preferível ao próprio ator do que as palavras contidas nessa frase realmente significavam ou não; quer dizer, o ator realmente usou a intenção exata da fala do texto.

Certamente para a Rússia de Stanislavski essa abordagem de personagem era apropriada a essa época. Mas ressalta a pesquisadora francesa Odette Aslan,"emocionar o público não é tanto o alvo procurado em nossos dias. Ficar emocionado para emocionar não é obrigatoriamente uma boa receita" (Aslan, 1974, p. 80).

Na realidade, no teatro contemporâneo, o personagem dentro da própria dramaturgia adota peculiaridades que inviabilizam este entendimento, pois, essa ruptura na tradição a partir da escrita exerce no trabalho do ator 0 desregramento na convenção de representação que Ryngaert menciona na citação que segue abaixo, modificando a concepção e os procedimentos técnicos de abordagem do personagem e do texto dramático. 


\begin{abstract}
Ensaiam-se formas para representar o mundo com regras que nem sempre derivam de Aristóteles. Contudo, e aí há um paradoxo, não pode haver ruptura radical com as antigas formas, ou melhor, apesar dessas rupturas, a matriz primeira continua sendo uma troca entre seres humanos diante de outros seres humanos, sob seu olhar que cria um espaço e funda a teatralidade. Portanto, há nos autores de hoje um desejo de romper com uma certa rigidez da representação tradicional. Essa crise, quando começa pela escrita, opera um desregramento nas convenções da representação (Ryngaert, 1998, p.6).
\end{abstract}

Podemos ver claramente este desregramento e ruptura nos textos de Bernard-Marie Koltés, Valère Novarina, Sam Shepard, Thomas Bernhard, Heiner Muller, Michel Azama e Robert Pinget, que se destacam internacionalmente pela vanguarda e inovação de seus textos, não só no que tange à noção de personagem como na estruturação completa de seus textos, que possibilitam exatamente esse romper do personagem já explicitado no texto. As informações obtidas no texto para o entendimento do personagem são dúbias ou ainda com múltiplos sentidos. $O$ ator, então, inicia o processo de criação do personagem com mais opções e, possivelmente, impondo entendimentos diversos. No Brasil, podemos usar como exemplo os textos dramáticos não aristotélicos do paranaense Mário Bortolloto, onde a construção do personagem está completamente aberta.

[...] a cena contemporânea aposta no fato de que "tudo é representável", isto é, nenhum texto está, a priori, excluído do campo do teatro por falta de teatralidade (Ryngaert, 1998, p.31).

Em relação à apropriação do texto dramático e os primeiros entendimentos do papel a ser representado, veremos o que disseram os seguintes atores: ator $A$ : “... eu preciso saber o que o personagem está dizendo, para quem e o porque..."; ator B: "Primeiro eu faço uma leitura branca, depois preciso entender o personagem no mundo, quem é ele, como se relaciona no texto com os outros personagens..."; ator C: "leio e releio o texto e me questiono sobre o contexto em que este personagem está inserido...; ator $D$ : "Leio o texto muitas vezes e escrevo sobre este texto. Reescrevendo o texto me faz memorizar e perceber possibilidades para este personagem. Entender 0 personagem é entender a trama. Preciso também entender o que o autor quer com o texto, em que tempo ele foi escrito e para quem...”; ator E: “... primeiro 
eu racionalizo o personagem. Estudo o porque ela age daquela forma. $O$ texto e o contexto..."; e o ator F: "...entendo o texto dramático a partir da minha realidade, por isso a primeira coisa que eu faço é ler o jornal...".

Essas citações resumem muito apropriadamente o que permeia a realidade da abordagem do texto no processo de construção do personagem. Conforme podemos ver através da análise das entrevistas, a maioria dos atores se apropria de um texto dramático, inicialmente o estudando e o relendo muitas vezes. Saber qual foi a intenção do dramaturgo ao escrever aquele texto e o que ele pretendia dizer ao mundo, para quem, o que, e o porquê se está dizendo aquele texto, entender o personagem no mundo e qual a relevância desse texto para o contexto atual do ator também são aspectos que se revelam como fundamentais nesse processo.

Existe também um trabalho de pesquisa muito intenso do dramaturgo a ser trabalhado, dos aspectos históricos que Ihe eram verdadeiros na época da criação daquele texto.

Apesar de toda a ambigüidade e abertura oferecidas pelos textos contemporâneos $e$ as diversas noções de personagem resultantes desse processo, os atores ainda mantém a necessidade de compor conexões, de criar justificativas para esses personagens. A procura de informações dos atores entrevistados sobre o dramaturgo, sobre o texto e principalmente sobre as características do personagem encontradas na obra servem para a construção de um subtexto de acordo com os estudos de Stanislavski:

Ações a executar, lembranças a evocar, movimentos cênicos, acessórios a manipular, constituem a partitura do papel, ou subtexto, o filme interior de imagens que provocam os sentimentos (Aslan, 1974, p77).

No que se refere à caracterização, observemos o que diz a atriz A: "...eu não gosto de pré-conceber um personagem, eu gosto que ele seja orgânico...", enquanto que $O$ ator $D$ diz: "Existe um processo mental das ações do personagem, como ele age anterior ao processo de criação, mas é na fisicalização que se define e que surgem, mais possibilidades da construção deste personagem..."; e o ator C: "Primeiro eu crio ações através de improvisações, segundo trabalho com falas e por último a caracterização. Não 
uso técnicas acadêmicas. Uso mais a intuição para me apropriar do texto."; e também o ator D: "Eu fisicalizo o personagem sem o texto e depois coloco o texto no meio da partitura de ações e vejo onde ele se encaixa melhor."; ator E: “Já me aconteceu de, no começo do texto, interpretar um personagem de certa forma e que, mais tarde, ele se revela de outra forma completamente diferente."; ator G: "Eu uso, simultaneamente, o intelectual e o prático, ler, intuir e experimentar. Tento compreender o texto e busco motivações dentro deste texto. As primeiras abordagens são práticas, deixando a minha intuição me orientar nesta prática. Não gosto de representações préconcebidas, por isso não leio o texto antes do encontro do grupo. O restante depende do diretor e da proposta do trabalho."; ator M: "O texto contemporâneo aberto permite várias construções e isso ajuda porque eu trabalho com a dissonância do personagem, com suas dicotomias. Eu sempre parto do trabalho físico e depois o texto. O que muitas vezes tu não descobres sentado lendo o texto, tu descobres na ação, e isso só é possível com o trabalho prático..."; e o ator $\mathrm{H}$ : "Gosto muito de fazer uma ficha do personagem. Construo a vida do personagem e depois adapto conforme concepção do diretor."

Em relação à caracterização do personagem, como podemos observar pelas citações acima, alguns atores pré-estabelecem, no estudo do texto, ações que poderiam servir para tal personagem, outros partem do trabalho físico e não do intelectual. Poucos atores utilizam-se da técnica de dividir o texto em unidades. Muitos deles recorrem à improvisação como ponto de partida da construção do personagem, mas sempre tendo as informações obtidas no texto como ponto de partida para criar as ações desses personagens.

A utilização de referências do cotidiano que aqui segue, aponta para a necessidade da personificação pelo ator do seu personagem, o encontro de suas próprias vivências e experiências. Diz uma das atrizes: “...procuro pessoas na vida real que reverberem o personagem. Uso imagens inconscientes, minha memória genética, meu material, até encontrar uma unidade entre atriz e personagem, fisicalizando essa memória aguçada pela pesquisa de campo." Poderíamos dizer que essa atriz se identifica com o princípio da memória emotiva de Stanislavski. 
Outro aspecto fundamental é a importância dada ao diretor em relação ao processo de construção do personagem e apropriação do texto, como podemos observar nas citações anteriores dos atores $\mathrm{G}$ e $\mathrm{H}$. De acordo com os entrevistados, o diretor necessita estabelecer uma proposta de trabalho. Dependendo dessa, o personagem surge do texto ou do trabalho físico.

O gênero dramático condiciona o trabalho. Existe uma pré-disposição de entendimento dos personagens conforme o gênero. Também esse aspecto foi delegado ao diretor: escolher a melhor maneira de proceder ao desenvolvimento da abordagem do texto. Podemos ressaltar uma observação feita pelo ator $C$, se não interessante, própria da cena contemporânea: "Mais importante seria o que o gênero dramático serve para atualidade do que como ele é abordado. Gêneros e formas devem ser respeitados mas devem servir mais como base do que como via de regra".

Todos os atores concordam que os textos dramáticos contemporâneos oferecem desafios ao processo de criação do personagem por apresentar uma estrutura muito aberta, sem muitas indicações precisas à fisicalização do personagem. Vejamos o que diz o ator $D$ em relação a esse aspecto: "A própria montagem de Miguel Pampa' era muito bela, esteticamente tinha imagens muito bonitas, mas a dramaturgia em si é uma dramaturgia de muita dificuldade...", provavelmente se referindo a dificuldade de encontrar elementos suficientes para a composição inicial do personagem, ou ainda o que diz o ator C: "Qorpo Santo muda de personagem. Não existe ambientalização espacial, não tem tempo, não tem personagem, ele entra e daqui a pouco já mudou de nome, mas é o mesmo personagem, e mais, em certos momentos você pergunta o que aquele personagem está conversando com outro mas é o mesmo personagem. Qorpo Santo é um contemporâneo que não é nosso contemporâneo".

O contrário, ou seja, encontrar já na dramaturgia, indicações estabelecidas pelo dramaturgo, as didascálias, também acontecem conforme o depoimento do ator E: 'Com o 'Fim de Partida' não se cortou nada do texto, foi o texto tal e qual. E esse dramaturgo dirige muito de fora o que ele quer: agora a pausa é aqui, agora tal personagem se vira, a tua criação é a partir do 
que ele colocou no papel. É como uma pessoa que não está junto mas que vai determinando a tua movimentação e a tua emoção."

Começamos a perceber que a ambigüidade que caracteriza o texto contemporâneo oferece desafios enormes na composição do personagem permitindo, também, o encontro de uma diversidade de leituras muito maior. Vejamos isso no que diz o ator G: "A possibilidade de existir diferentes leituras para um mesmo texto dramático é maravilhoso. Isso não trai a obra, bem pelo contrário, é nessa medida que eu faço Shakespeare ser eterno".

Todo o processo criativo é seletivo. A primeira função do ator é retirar do texto informações relevantes e buscar elementos e então selecioná-los. Usando a intuição, o ator pode simultaneamente unir o trabalho intelectual ao prático. Nas primeiras abordagens práticas do personagem, 0 ator pode orientar movimentos, gestos, foco, conforme intuições pré-concebidas no estudo do texto. $O$ ator em conflito com diversas abordagens precisa optar pela mais teatral.

A noção do subtexto de Stanislavski também está presente nos depoimentos do ator G: "Eu não posso começar pela palavra. Eu tenho que começar pelo que motiva esta palavra". Entretanto as motivações que agora fazem parte do texto não estão tão evidentes como nos textos de Tchekov. $O$ texto contemporâneo perdeu o sentido da lógica realista.

\section{Encanto cênico}

O ator co-habita cada vez mais com um aparelho cênico complexo. As inovações no figurino, na iluminação, no cenário ou espaços cênicos alternativos, nos acessórios usados em cena para diversificar a atuação, nunca estiveram tão em evidência como no começo do século XXI. O uso da água, da terra, do vento, de projeções cinematográficas ou de vídeos, de materiais diversos com efeitos de luz e fumaça, bem como as acrobacias, as pirotecnias e o circo estão presentes nas encenações pós-contemporâneas, se é que podemos defini-las como tais. É dentro desse contexto que o ator busca encontrar a sua própria força, o seu poder de encanto cênico. 
Stanislavski acreditava que o encanto cênico, como ele mesmo assim denominava, constituía o resultado da veracidade de sua ação, veracidade esta garantida por uma expressividade carregada de emoção.

\begin{abstract}
Partindo da biografia da personagem, de seu comportamento, das circunstâncias da ação, o ator procede "como se", entra em um processo psicológico que desencadeia nele o sentimento real, ele "vive" o acontecimento e suas conseqüências, em vez de contentarse em reproduzir a manifestação exterior de um sentimento que ele não sente. Ele instaura uma motivação verdadeira, ele se põe em jogo de atuação. [...] O psíquico arrasta o físico, é a escola do "reviver", oposta à escola da "representação" (Aslan, 1974, p. 76).
\end{abstract}

Além da disciplina rigorosa com que levou sua vida e pesquisa no teatro, Stanislavski, incentivado pelo público e também pelos dramaturgos da época que desejavam uma representação menos calcada na entonação e nos gestos exagerados, considera o personagem como representação legítima de um indivíduo. Todas as ações do ator em cena devem ser lógicas, coerentes e possuir um objetivo que colabora para desenhar o que chamou de "linha contínua de ações do personagem", essa entendida como verossímil dentro de um padrão realista. Nesse processo, a manifestação de emoções subconscientes aparece em Stanislavski como fundamentais para sustentar a veracidade da ação dramática do texto. Um dos primeiros procedimentos empregados por Stanislavski no despertar das emoções, foi o trabalho sobre a memória emotiva.

\footnotetext{
A lembrança de uma experiência pessoal do comediante pode ajudálo em cena e desencadear uma emoção análoga àquela que deve experimentar a personagem. [...] Stanislavski, para provocar uma emoção sincera, recorre a um recurso enganoso (Ibidem).
}

Ainda em sua época, outras respostas surgiram como reação ao naturalismo. Edward Gordon Craig, apesar de nunca ter conseguido atingir seu objetivo de pesquisa, se baseia na noção do ator supermarionete onde o corpo do ator estaria em um estado de êxtase e onde ele fosse além da vida. $\mathrm{Na}$ verdade, Craig queria um teatro sem o ator. Importava-se muito mais pela ação do que pela palavra dita e pela encenação do que propriamente pelo trabalho do ator. Suas anotações nos servem para suscitar a ética do ator de renunciar a ambição pessoal para a garantia de algo bem mais grandioso: a teatralidade. 
Assim sendo, Craig via o encanto cênico do ponto de vista da marionete, ou seja, o ator como mais um dos elementos constituintes da cena, assim como a luz, o cenário, etc.

Meyerhold, por sua vez, elaborou a biomecânica. Os seus atoresacrobatas recebiam treinamento rigoroso possibilitando uma maior importância dada ao gesto do que à palavra. A biomecânica seria uma vertente das ações físicas de Stanislavski sem o aspecto psicológico que as envolvia. Meyerhold, por sua vez, percebia o encanto cênico no movimento: "Se o ator tiver bons reflexos, a partir de um movimento adequado, um sentimento adequado é excitado" (Ibidem).

Não importa qual fase de suas pesquisas Stanislavski se encontrava, ele sempre reconhecia a necessidade de revigorar, a cada representação, a verdade que garantiria, segundo ele, a força cênica do ator.

[...] o comediante pode reviver o papel centenas de vezes, sem prejuízo para a qualidade de sua emoção (cumpre, aliás, desempenhar um papel centenas de vezes para interpretar sua quintessência) (Ibidem).

O terceiro aspecto de nosso interesse volta-se para os fatores que norteiam, no entendimento contemporâneo, a força da presença cênica do ator e seu sistemático processo de re-vigor.

Os atores acreditam em dilatação corpórea, uma expansão voluntária da massa corporal que acontece em cena, um estado extra-cotidiano que eleva $o$ ator a um estado "ultra-cotidiano, ultra-naturalístico que falava Stanislavski" como dito pelo ator $\mathrm{M}$ em um de seus depoimentos. É ele que continua: “...para estar com presença em cena é necessário estar carregado de energia, é estar cheio de vida, é o que faz o ator dilatar o seu corpo, é essa vivacidade que o Artaud falou, não esse cotidiano entediante em que nós vivemos...". Outro ator, o ator J, diz: "é estar vivo em cena, vivo no sentido de passar a emoção que o personagem tem que passar, é conseguir fazer a triangulação com o público [...] sem energia você não consegue envolver o público...". Como podemos observar as palavras vida e público são muito levadas em consideração na questão presença e energia. Continuemos analisando o que diz o ator $B$ : “...quando não há presença cênica o espetáculo não existe, então eu, como 
público, fico pensando na minha vida, nas contas para pagar..."; ou então o ator E: “...presença cênica é tu estares vivo ali na hora, é esse transporte, te transportar do teu mundo cotidiano e abrir uma brecha e estar ali respirando como o personagem, é esse poder de te transformar e ser realmente aquele personagem [...] quando não há presença, o público tem menos empatia com o personagem...". Stanislavski acreditava que essa vida, que tanto falam esses atores, é resultante do trabalho psíquico que traz o físico à tona. Físico esse, resultante de um processo mental e emocional. É como se essa interiorização de emoções dilatasse o corpo.

Parece-nos, também, que algumas das citações que se referem à vida têm o cunho político tanto estudado e praticado pelo teatro de Brecht. Precisamos lutar contra o tédio que esvazia nossas vidas e é no teatro que ganhamos essa força viva, ou seja, servir exatamente como intermediário entre essa idéia revolucionária, portanto, política, e o público.

Outros atores percebem presença e energia cênicas de maneira diferente: conforme $\mathrm{o}$ ator $C$ : "são palavras muito subjetivas mas acho que estão interligadas...", reforçando a idéia do ator $C$, o ator $F$ diz: “...presença cênica é um pouco subjetivo, por que tem pessoas que tem carisma? Ou você tem ou não tem, é algo que não depende de técnica..."; e o ator G: "Energia é o que te habilita em cena, o que te dá o ritmo, o que té dá movimento [...] é o que te faz pulsar, é como o atleta que se prepara para o seu esporte, tu realizas a ação antes dela acontecer fisicamente...". Este ator está se referindo à préexpressividade, o gesto mental anterior a própria ação física.

Um dos questionamentos mais profundos do trabalho é em relação à cristalização do personagem e os procedimentos empregados por esses atores entrevistados na hora de lidar com esse problema, que ronda o fazer teatral, particularmente após a estréia e como preservam o vigor de suas atuações. Diz o ator I: “... tem elementos externos, o público, por exemplo, o local onde está sendo feita a apresentação, porque esses elementos influenciam diretamente no trabalho do ator, um público nunca é igual ao outro, ou seja, a interação com o público será diferente a cada noite..." e, semelhante a essa idéia, diz o ator M: “... a apresentação sempre será diferente porque eu estou diferente naquele dia [...] o teatro é um ato de comunhão com o público, então as pessoas irão 
reagir diferentemente a cada noite...". Esses atores recorrem a fatores externos para não apenas reproduzirem atuações, é contracenando com o público que empregam forças novas a cada apresentação. Enquanto que outros atores recorrem muito ao processo de criação para renovar sua atuação mesmo sendo esta a centésima apresentação. Vejamos o que diz o ator A: “... desde o alongamento trabalhar em função do que você sente que mais precisa naquele dia, puxo o meu próprio tapete, arrisco durante a cena..."; já o ator G diz: “...voltar a trabalhar fisicamente com o personagem durante a temporada respiração, movimentos, falas..."; enquanto que o ator $C$ pensa que: "...sempre durante o aquecimento eu tento trazer de volta as coisas que eu pesquisei, que eu trabalhei no processo de criação, as coisas que me motivaram...". Igualmente ao ator $C$, age o ator $B$ : “... eu repasso cenas antes de começar o espetáculo para não cristalizar, recorro aos ensaios, tento relembrar o que eu fiz nos ensaios para criar aquela cena...". E alguns deles se fundamentam nas motivações que os levaram a criar aquele gesto, ou fala, ou ação naquele dado momento da peça como diz o ator G: “... o que você tem que estar recriando são as motivações que te levaram a constituir aquela cena daquela maneira, a optar por esta abordagem, por este comportamento do personagem..."; o ator F: “...às vezes é uma palavra, um gesto e tu resgatas esta emoção...", e o ator G novamente: "...tu tens que recriar as tuas motivações [...] trabalho fazendo anotações durante o processo de criação daquele momento de descoberta e, na cena, tu vais redescobrindo as tuas motivações".

Stanislavski acreditava na emoção, como mencionado previamente, para fundamentação do personagem; Brecht no distanciamento, na força política e social como geradoras de uma encenação. Destaquemos algumas declarações em relação a este aspecto: Enquanto o ator I diz: “...sim, empresto a minha emoção ao personagem com um certo distanciamento, é claro. O representar em si é a união da técnica com os sentimentos, razão e emoção, são as duas divindades do teatro Dionísio e Apolo...”; o ator F, entretanto, diz: “... o ator não sente nada, o ator não sente ciúmes da atriz que faz a Desdêmona, quem sente é o público, esse sim, pagou para sentir, esse sentimento é verdadeiro, o do público, o do ator é simbólico, eu sinto medo de errar o texto, eu sinto insegurança porque o contraregras esqueceu de botar a arma na gaveta, isso é 
verdadeiro [...] você se comporta emocionalmente como personagem mas não sente nada na verdade, mas sente numa outra ordem [...] meu sentimento é simbólico e não sintomático...". E o ator $G$ continua: “... a emoção do ator se dá por imagens, o ator se emociona com a situação do personagem então ele chora, é uma emoção técnica [...] Stanislavski se esgotou emocionalmente com o trabalho da memória afetiva, mais tarde trabalha com o método das ações físicas, ele vai trabalhar a emoção através da forma [...] ele nunca propõe ao ator embotar os seus sentimentos, ele queria que o ator trabalhasse sensivelmente e que tivesse consciência..."; e o ator F completa.“...é a mesma coisa quando a gente entra no velório de um estranho, a gente não sente nada pelo morto mas nós nos contagiamos...". Existe uma incerteza quanto a esse aspecto. Os atores se contradizem ao tentarem explicar esta difícil questão. Stanislavski acreditava na emoção como geradora de presença cênica e não na energia como acreditam os atores entrevistados. Da mesma forma quanto a Brecht, ou seja, não adianta criarmos um distanciamento se não estivermos politicamente engajados com esse tipo de teatro.

\section{Competências fundamentais}

Das competências fundamentais que o ator deve ter em cena, observamos que os atores entrevistados reconhecem os seguintes aspectos na arte da representação: entendimento do contexto em que se situa o personagem e conhecimento da fala em relação a esse contexto, conforme podemos observar nas três citações que seguem. Diz o ator $A$ : “... primeiro, antes de mais nada, a principal é ter verdade em cena. Verdade no sentido de saber o que se está fazendo ali, saber por que se está fazendo aquilo ali, o que se quer dizer em cena..."; e o ator M: “...fundamental em cena? Presença. E a segunda coisa importante é a apropriação do que ele (ator) está dizendo. Ter absoluta certeza do que ele está dizendo, saber tudo que ele está dizendo, seja com o corpo ou seja com o corpo invisível que é a voz. Ter segurança. E essa segurança vem do tanto que tu pesquisaste, do tanto que tu sabes do que tu estas falando, seja no sentido assunto quanto linguagem..."; e mais o ator $D$ : “...uma 
compreensão do personagem dele, da linha dramática que o personagem tem dentro da ação..."

Outro aspecto fundamental destacado pelos entrevistados é em relação à generosidade e concentração necessárias para haver jogo e presença cênica, respectivamente. $O$ ator $G$ pensa que "[...] $O$ ator tem que ser generoso, ele não está sozinho mesmo que ele esteja fazendo um monólogo, nunca. "Ele tem uma equipe atrás dele, ele tem um diretor junto com ele, ele tem o público, ele tem os companheiros, ele tem os atores e isso é fundamental..."; da mesma maneira, o ator H: "A principal para mim é a generosidade. Acho que um ator tem que ser extremamente generoso em cena. Ele tem que compreender que teatro é jogo, é um trabalho de troca, de contracenação..." semelhante ao ator E: "Tu tens que estar aberto, tens que estar desperto porque o concentrar não é concentrar-se em si e sim concentrar-se no que está acontecendo, estar presente. Acho que esta presentificação é a principal qualidade, a básica mesmo..."; e também o ator L: "...Eu acho fundamental generosidade e estar aberto para o jogo com o colega, contracenação...”; e o ator J: “...é estar atento. Tu poderes proporcionar com que teu colega venha a contribuir com a encenação [...] ...tu tens que ter concentração, tens que ter tônus, tens que ter atenção, tens que ter generosidade, pensando em cena tu tens que, dentro do possível, ter entendimento do ritmo do espetáculo...".

Alguns aspectos técnicos também são explorados nas entrevistas, destacando-se entre eles o domínio corporal relacionado aos limites do próprio ator que deve, conseqüentemente, ter um preparo e treino físico muito grande para conseguir atingir um estado extra-cotidiano necessário para a cena e também necessário para o jogo, ou seja, a contracenação, conforme palavras do ator G: "Eu acho que as qualidades fundamentais de um ator em cena são obviamente relacionadas com as qualidades do ator. O que faz o bom trabalho, o bom ator, vamos dizer assim, então eu acho que a primeira coisa que se exige de um ator é que ele tenha disciplina de trabalho, que ele conheça os seus limites físicos e psicológicos e que ele saiba trabalhar criativamente com estes limites [...]o ator ocupando um espaço, a presença do público, a relação com os outros atores em cena, eu diria que, o que se espera de um ator em cena é que ele tenha domínio do seu instrumental, presença cênica, que ele 
saiba usar sua voz e que ele tenha principalmente consciência do que ele está fazendo em cena...".

Podemos, então, resumir assim os aspectos fundamentais do ator em cena: a compreensão do texto e do personagem, generosidade, preparo físico e atenção.

Analisemos agora o que dizem os atores sobre a relação entre técnica e intuição criadora. $O$ ator $L$ acredita que: “...elas não estão separadas, a técnica já está embutida, eu vou com a minha intuição e a técnica já está trabalhada no meu corpo, mas eu não fico usando racionalmente técnica e intuição"; já o ator $H$ diz: "...é uma relação de conflito. Geralmente são os acadêmicos que defendem a técnica, tem uma outra corrente que defende um processo mais intuitivo..."; ou ainda: "...eu acho que as duas tem que andar juntas [...] esses caras que tentaram organizar essas técnicas, o próprio Stanislavski apontava caminhos para o ator, vai por aqui, vai por ali que é mais fácil, busca na tua memória, busca na tua experiência, busca no teu inconsciente [...] eu sinto falta de buscar um método mais produtivo. Parece que a técnica ajuda até certo ponto e depois tu tens que preencher com o que é teu, com a intuição [...] intuitivamente eu fui descobrindo a técnica no teatro.", e da mesma forma o ator M: "...saber despertar a tua intuição é técnica [...] quando tu não vês a técnica é que ela existe [...] acionar o teu emocional para colocar ele a serviço da cena é ter técnica, é quando a gente não vê a técnica no corpo do ator que ela existe...". Ainda podemos destacar os depoimentos do ator F:“...elas convivem maravilhosamente bem, tu tens que, tecnicamente, encontrar uma maneira de formar aquilo que tu intuis..."; e mais: "...existe o artista e o ator. $O$ artista é que tem a intuição, ele vibra, ele é louco, o ator é como um piano bem afinado que dá forma, por isso tu tens que saber fazer o teu corpo responder aquilo que a tua mente enlouquecida inventa..."; e do ator G: “...a técnica é apenas um elemento que permite ao ator formalizar bem o seu trabalho, porque se tu não tens um instrumento afinado tecnicamente, tu estarás sempre aquém do que tu poderias ser, ou vai estar sujo, ou confuso, ou pequeno, a técnica é que limpa o trabalho, é o que dá clareza e é o que te possibilita usaro teu corpo, tua voz, a tua emoção de maneira produtiva..."; e também do ator E:“...técnica é o saber fazer, é como virar estrelinha, eu tenho que dominar este 
movimento para depois o personagem poder fazer estrelinha em cena [...] a técnica está a serviço da criação [...] ter uma rotina de treinamento te deixa o corpo mais disponível..."; e por último do ator C: “...a técnica é fundamental mas a intuição tem a mesma importância [...] quando a coisa é muito técnica eu acho que ela se torna fria, eu, particularmente, não me interesso em só usar a técnica, torna o trabalho muito racional, quando um ator trabalha só com técnica o trabalho me parece sempre menos saboroso...".

É visível como os atores concordam nesse aspecto, que a técnica é o treinamento corporal que possibilita ao ator intuitivamente construir o seu personagem. Parece difícil desmembrar a técnica e a intuição no processo de criação e do que acontece durante a encenação. Isso significa que elas estão correlacionadas tanto no surgimento do personagem quanto na sua manutenção. A técnica é o que possibilita o ator deixar vazar toda a sua imaginação, permanecendo a primeira invisível aos olhos da recepção, exigência essa muito encontrada nos depoimentos citados. Porque quando ocorre o contrário, isto é, quando a técnica se faz presente aos olhos da platéia, o resultado, segundo os entrevistados, não é satisfatório. Craig, no treinamento com seus atores, exigia muita disciplina corporal mas não deixava seus alunos privados de um processo imaginativo paralelo a esse primeiro: "Esse rigor não impede Craig de querer desenvolver o espírito de observação e a invenção criadora de seus alunos” (Aslan, 1974, p.103).

$A$ arte do ator sempre se mostrou como um desafio para aqueles que tentaram teorizála. A definição de sistemas de análise dos diferentes aspectos da atuação cênica e de metodologias técnicas para uma atividade humana tão subjetiva e abstrata, ainda está em estágio inicial, se considerarmos que os estudos teóricos da arte da representação são recentes, datados do início do século $X X$, não se considerando aqui a Commedia dell'Arte.

Apesar disto, os atores estão cada vez mais conscientes da necessidade de um estudo teórico-prático para embasar o exercício de sua arte, buscando procedimentos que os qualifiquem no processo de abordagem do personagem.

A cena contemporânea tem diversificado o trabalho do ator $e$, conseqüentemente, ele busca descobrir e entender os recursos necessários para acompanhar a evolução da arte da representação no panorama atual. 
Nem todos os grandes teóricos da arte do ator, como Stanislavski, Craig, Meyerhold, Brecht e Artaud tiveram a oportunidade de testemunhar seus estudos transformados em efetivos resultados cênicos. Porém, suas investigações parecem seguidamente servir, ainda hoje, de suporte ao exercício da atuação. Se, por um lado, o ator de hoje surge melhor fundamentado teoricamente, por outro, não relaciona seu trabalho a uma única teoria de interpretação. Observa-se o emprego de distintos procedimentos técnicos e, muitas vezes, o ator desconhece a origem investigativa da técnica empregada.

Descubro que estamos diante de uma nova etapa da arte da representação. Como ator, e compartilhando desse estudo com meus colegas, percebo que não estamos sabendo o que realmente fundamenta a nossa arte, apesar de termos noção do que existe em relação a teorias adjacentes de tal arte. A diversidade da cena contemporânea gera uma angústia de saberes sem aprofundamento.

Este trabalho tentou organizar os procedimentos do ator nos vários processos de seu trabalho e, como a nossa arte é subjetiva, certamente mudanças em relação subjetiva, certamente mudanças em relação a certamente mudanças em relação a essas conclusões já devem estar ocorrendo na cena contemporânea, abrindo, portanto, a possibilidade de continuidade dessa pesquisa. 


\section{REFERÊNCIAS BIBLIOGRÁFICAS:}

ASLAN, Odette. O Ator no Século XX. São Paulo: Perspectiva, 1974.

ARTAUD, Antonin. O Teatro e seu Duplo. São Paulo: Max Limonad, 1984.

BARBA, Eugenio. A Canoa de Papel - Tratado de Antropologia Teatral. São Paulo:

Hucitec, 1994. BARBA, Eugenio. Além das Ilhas Flutuantes. São Paulo/Campinas: Hucitec, 1991.

BROOK, Peter. Ponto de Mudança. Rio de Janeiro: Civilização Brasileira, 1994.

BROOK, Peter. A Porta Aberta. Rio de Janeiro: Civilização Brasileira, 1999.

FURASTÉ, Pedro Augusto. Normas Técnicas para o Trabalho Científico. Porto Alegre:

s.n.,2004.

GROTOWSKI, Jerzy. Em Busca de um Teatro Pobre. Rio de Janeiro: Civilização Brasileira, 1976.

LANGER, Susanne K. Sentimento e Forma. São Paulo: Perspectiva, 1980.

MEYERHOLD, V. Teoria Teatral. Madri: Fundamentos, 1976.

NESTROWSKI, Arthur (org.). Trilogia Bíblica. São Paulo: Publifolha, 2002

OIDA, Yoshi. Um Ator Errante. São Paulo: Beca, 1999.

OSTROWER, Fayga. Criatividade e Processos de Criação. Petrópolis: Vozes, 1978.

PALLOTTINI, Renata. Dramaturgia - A Construção do Personagem. São Paulo: Ática, 1989.

PALLOTTINI, Renata. Introdução à Dramaturgia. São Paulo: Ática, 1988.

PAVIS, Patrice. Dicionário de Teatro. São Paulo: Perspectiva, 1999.

RYNGAERT, Jean-Pierre. Introdução à Análise do Teatro. São Paulo: Martins Fontes, 1996.

RYNGAERT, Jean-Pierre. Ler o Teatro Contemporâneo. São Paulo: Martins Fontes, 1998.

SPOLIN, Viola. Improvisação para o Teatro. São Paulo: Perspectiva, 1979.

STANISLAVSKI, Constantin. A Preparação do Ator. São Paulo: Civilização Brasileira, 1999.

STANISLAVSKI, Constantin. A Construção do Personagem. Rio de Janeiro: Civilização

Brasileira, 1979.

STANISLAVSKI, Constantin. A Criação de um Papel. Rio de Janeiro: Civilização Brasileira, 1980. 